\title{
Demutualization in Developing and Developed Country Stock Exchanges
}

\author{
Muhammad Hammad, ${ }^{*}$ Adil Awan, ${ }^{* *}$ Amir Rafiq ${ }^{* * *}$
}

\begin{abstract}
This study considers seven different stock exchanges in order to measure the impact of demutualization announcements on stock market return volatility. This is measured based on the daily index prices of all seven indices: the Toronto Stock Exchange (TSX) in Canada, the FTSE 100 in the UK, the Straits Times Index (STI) in Singapore, the Nikkei 225 in Japan, the Kuala Lumpur Composite Index (KLCI) in Malaysia, the SENSEX in India, and the Hang Seng Index (HSI) in Hong Kong, China. A dummy variable is used to differentiate between pre- and post-event data. We use the augmented Dickey-Fuller test, the ARCH LM test and GARCH $(1,1)$ methodology to measure return volatility due to demutualization announcements. The results show that the decision to demutualize did not affect the UK, Singapore, and Indian stock markets, where volatility is explained by other factors. It did, however, affect the Canadian, Japanese, Hong Kong, and Malaysian stock markets. Moreover, the Canadian and Malaysian market swere negatively affected, while the Hong Kong and Japanese markets reacted positively to the demutualization announcements.
\end{abstract}

Keywords: demutualization, stock market, GARCH.

JEL classification: G150, G170, C220.

\section{Introduction}

Conventionally, stock exchanges have worked as a "club of brokers" under a mutual operating system, who enjoy the rights of ownership and decision-making. Stock exchanges have faced a number of challenges in recent years due to technological advancements and improvements, growing competition and globalization. Consequently, many stock exchanges are now rethinking their investment decisions, regulatory reforms and aggressive environment. The challenge for stock

${ }^{*}$ MS student, SZABIST, Islamabad.

${ }^{* *} \mathrm{PhD}$ student, COMSATS, Islamabad.

${ }^{* * *}$ Assistant professor, SZABIST, Islamabad. 
exchanges is to find new opportunities in the present environment, while surviving new threats.

The different forms of demutualization have become a widespread reality with growing demand in emerging markets (Elliott, 2002). In this context, stock exchanges have developed new business models and governance structures to counter their competition, transforming from members' associations to for-profit organizations; this is the process of demutualization. Exchange demutualization begins when the members of a traditional nonprofit organization that operates a stock exchange reorganizes it as a for-profit institution. It concludes when the exchange goes public and becomes listed.

Exchange demutualization is the process of converting a mutually owned association into a limited company by share. In this conversion, decision-making rights are transferred from the members' association to the number of shares issued (the shareholders). Demutualization is important if, in a competitive environment, the exchange shifts its focus from working in the best interests of its members or brokers to working to maximizes hare holder equity by providing services to its customer, i.e., investors and brokers. The Stockholm Stock Exchange was the first exchange to be demutualized in 1993. By 1999, 11 others had also been demutualized. By2002, almost 21 exchanges had been demutualized and listed (see also Table A1 in the Appendix).

Citing a survey conducted by BTA Consulting to determine the objectives behind exchange demutualization, Scullion (2001) highlights the following: (i) attracting new investors to meet the capital requirements for modifying a trading system, (ii) creating an unbiased business environment, (iii) controlling the cost of transactions, and (iv) creating a competitive and flexible environment that promotes efficiency. The impact of exchange demutualization is often studied in the context of how it affects the structure of an organization. Our aim, however, is to look at its impact on the financial market in terms of efficiency, profitability, and governance structure and to determine whether this structural change affects security prices.

Specifically, we will measure the impact of demutualization announcements on a sample of seven stock exchanges in different developed and developing countries. We will examine whether, and to what extent, stock market volatility rises or falls in these countries after 
demutualization is announced. The study is limited to seven demutualized exchanges and spans a 12-year sample period.

Earlier studies have used different indicators to measure the impact of demutualization on stock exchange liquidity (e.g., Krishnamurti, Sequeira, \& Fangjian, 2003; Treptow, 2006), efficiency (e.g., Serifsoy, 2008), and cost and trading volume (e.g., Hazarika, 2004). Krishnamurtiet al. (2003) and Hazarika (2004) conduct a comparative analysis of ownership structure for two stock exchanges. Mendiola and O'Hara (2003) use five measures of performance-return on assets, financial leverage, return on equity, profitability, and asset turnover-applied to eight stock exchanges. Morsy and Rwegasira (2010) carry out a pre- and post-event analysis of the impact of demutualization on stock exchange performance, based on a sample drawn from the World Federation of Exchanges. Worthington and Higgs (2005) determine the market risk of four stock exchanges, but focus mainly on the post-demutualization period.

In this context, the present study aims to contribute to the literature by using the event of demutualization announcements to measure volatility in the stock market. Having identified trends in volatility pre-and post-demutualization, we then analyze the performance of developed and developing country stock markets. On the basis of these results, the study makes recommendations for Pakistan's stock market, which is in the process of demutualization. To our knowledge, this is the first study to measure the impact of demutualization on stock exchanges using stock exchanges indices as a measure of market performance.

\section{Literature Review}

This section presents an overview of the empirical and theoretical studies that measure the impact of demutualization on stock exchanges.

Hart and Moore (1996) observe that, in an environment of relatively high competition, outsider-owned structures are socially preferable to mutually owned structures. Schmiedel (2001) uses a parametric stochastic frontier model to estimate cost efficiency in a sample of European stock exchanges during 1985-99. The regression analysis indicates that demutualization has a positive effect on cost efficiency. Schmiedel (2002) uses a nonparametric model to estimate stock exchange efficiency during 1993-99, but observes no clear link between liquidity and demutualization.

Krishnamurti et al. (2003) compare the market quality of the demutualized National Stock Exchange and the mutually owned Bombay 
Stock Exchange (BSE) in India. Using the Hasbrouck measure (to compute the variance of the pricing error) of market quality, they conclude that the National Stock Exchange provides a better-quality market than the BSE. Treptow (2006) studies securities that are listed simultaneously on two markets and finds that demutualization has a significant and positive effect on the liquidity of demutualized exchanges. Moreover, postdemutualization, their turnover and liquidity gap increases.

Ahmed, Butt, and Rehman (2011) examine the benefits of demutualization in Pakistan based on the literature available; these include better corporate governance, access to economic and human capital, enhanced listings, and international alliances. Islam and Islam (2011) study the implications of demutualization and conclude that its benefits are not applicable in the context of Bangladesh.

Karmel (2000) finds that, when stock exchanges become for-profit organizations, their governance structure and market capitalization improves. After the demutualization of the Stockholm Stock Exchange in 1993, many other stock exchanges followed suit in the form of mergers and issued shares to become for-profit companies (Serifsoy, 2008). Hazarika (2004) studies the impact of demutualization on cost and trading volume for the London stock exchange with respect to high competition and for the Borsa Italiana, which was mutualized by the government. The study shows that stock exchanges that were demutualized due to competition are better off, but that exchanges that were demutualized for reasons other than competition are worse off.

Mendiola and O'Hara (2003) carry out a performance analysis of publicly listed and other listed companies using their respective share prices. They find that listed stock exchanges generally outperform both the stocks on their market and the IPOs listed on these exchanges. Hence, there is a positive link between stock exchange performance and the fraction of equity sold to other investors. Worthington and Higgs (2005) study the market risk of four demutualized and self-listed stock exchanges. They estimate the time-varying beta using a bivariate generalized autoregressive conditional heteroskedastic (GARCH) model for a sample of stock exchanges that were demutualized and listed by7 June 2005. Their results indicate significant beta volatility.

Morsy and Rwegasira (2010) study the impact of demutualization on stock exchange performance by incorporating 16 different market 
measures. ${ }^{1}$ They find that demutualization leads to an improvement in only seven of these measures (the number of listed companies, total transactions, capitalization of the domestic market, total value of share trading, new capital raised by IPOs, and velocity of turnover).

\section{Data}

The data used in this study comprises the daily index returns of seven selected stock exchanges, all of which are members of the World Federation of Exchanges. We employ six years of data, pre- and postdemutualization, to capture volatility trends. For the sample of developed countries (Canada, the UK, Singapore, and Japan), we use the Toronto Stock Exchange (TSX), the FTSE 100, the Straits Times Index (STI), and the Nikkei 225, respectively. The indices for the developing countries or economies selected (Malaysia, India, and Hong Kong, China) are the Kuala Lumpur Composite Index (KLCI), the BSE SENSEX, and the Hang Seng Index (HSI), respectively.

The study has employed only those stock exchanges that had been demutualized by2004 and for which at least six years' pre- and postdemutualization data were available. This particular sample will enable us to comment on the demutualization of Pakistan's stock exchange (9 May 2012) in the light of other developed and developing country exchanges.

\section{Methodology}

The unit of analysis in this study is the stock market. We carry out a descriptive analysis to determine the temporal or stochastic properties of the data. The daily returns of each stock exchange are calculated as follows:

$$
Y_{t}=\ln \left(\frac{P_{t}}{P_{t-1}}\right)
$$

Generally, financial time series contain a unit root, i.e., they are nonstationary, which can yield dubious regression results. Therefore, in order to obtain a representative result, it is necessary that the time series should be stationary. Both the augmented Dickey-Fuller (ADF) test and Philips-Perron test can be used to determine stationarity, but the ADF

${ }^{1}$ Number of listed companies, total transactions, capitalization of domestic market, capital raised by domestic companies, value of bonds listed, total value of share trading, new capital raised by IPOs, turnover velocity of domestic shares, market capitalization of newly listed shares, number of bonds issuers, number of bonds listed, average value of transactions, capital raised by bonds, and value of bonds trading. 
test is considered more reliable in the case of time-series data because it ensures a white-noise residual in the regression (Patra \& Poshakwale, 2006). We reject the null hypothesis of a unit root when the value of the $t-$ statistic is significant:

$\mathrm{H}_{0}$ : There is a unit root (nonstationary) in the time series

$\mathrm{H}_{1}$ : The series is stationary

The first step is to check the unit root of the series to establish the order of integration. This is done using the GARCH methodology to measure changes in the structure (conditional variance) and level of volatility (unconditional variance in error term).

Homoskedasticity or the constant variance of an error term is a basic assumption of ordinary least squares. The violation of this assumption forms the basis of the autoregressive conditional heteroskedastic $(\mathrm{ARCH})$ model: only those time series are heteroskedastic that's how signs of time-varying variance or volatility. The $\mathrm{ARCH}$ condition implies that, in a time-series analysis, the variance of the error term in a specific period is dependent on the variance of the error term in the preceding period.

The main function of the ARCH models introduced by Engle (1982) was to model and forecast the conditional variance. Subsequently, the ARCH model was generalized by Bollerslev (1986) as the GARCH model. The general GARCH $(p, q)$ model comprises a $p$ term, which indicates the number of autoregressive lags, and a $q$ term, which $\mathrm{h}$ indicates the number of moving average lags. The GARCH $(1,1)$ model shows the first-order $\mathrm{ARCH}$ term and first-order GARCH term.

The GARCH model has two specific equations: a conditional mean equation and a conditional variance equation. The conditional mean equation is written as

$$
Y_{t}=a+b y_{t-1}+\varepsilon_{t}
$$

where $\varepsilon_{t} \sim N\left(0, h_{t}\right)$

The conditional variance equation is:

$$
h_{t}=\omega+\alpha \varepsilon_{t-1}^{2}+\beta h_{t-1}
$$


where $\omega 0, \infty 0, \beta \geq 0$

The conditional variance equation comprises three terms: (i) a constant, $\omega$ (ii) the volatility of the previous period, $\alpha \varepsilon_{t-1}^{2}$ (the ARCH term), and (iii) the forecasted variance from the previous period, $\beta h_{t-1}$ (the GARCH term).

The coefficients of the GARCH model are easy to interpret and capture the propensity for volatility clustering (Joshi \&Pandya, 2008), which arises in financial data because any new information leads to a change in volatility (Engle\& $\mathrm{Ng}$, 1993). This makes it important to determine the effect and tendency of security return dispersion due to new and old information.

Samanta and Samanta (2007) observe that the GARCH model measures the persistency of market volatility because it has two effects on the market: that of recent news (the ARCH effect) and that of old news (the GARCH effect). The volatility due to current news is determined through the variation in the results of these effects. In financial data, the ARCH effect captures the persistency of shocks in the short run, while the GARCH effect captures the long-run persistency of volatility due to shocks (Morimune, 2007). $(\alpha+\beta)<1$ is a sufficient condition for variance stationarity. If the combined value of $\alpha$ and $\beta$ s closer to 1,this indicates volatility clustering in the data. If, in extreme cases, $(\alpha+\beta)=1$ or $(\alpha+\beta)=0$, this indicates that the shock is permanent or will die out soon, respectively.

A dummy variable is used to divide the data into pre- and postdemutualization data, where 1indicates pre-demutualization data and 0 , post-demutualization data.

\section{Results and Discussion}

Table 1 gives the results of the ADF test for all series. All seven series are stationary in levels with absolute significant values:-35.65, 47.74, 42.43, 41.33, 27.22, 50.60, and 24.01 for the UK, Singapore, Canada, Japan, Hong Kong, India, and Malaysia, respectively. The p-value is less than 0.05, which implies that we can reject the null hypothesis of a unit root. 
Table 1: Results of ADF test

\begin{tabular}{|c|c|c|c|c|}
\hline Market & & Level & t-stat & Prob.* \\
\hline \multirow[t]{4}{*}{ UK } & ADF test statistic & & -35.65185 & 0.0000 \\
\hline & Test critical values & $1 \%$ & -3.432319 & \\
\hline & & $5 \%$ & -2.862296 & \\
\hline & & $10 \%$ & -2.567216 & \\
\hline \multirow[t]{4}{*}{ Singapore } & ADF test statistic & & -47.74135 & 0.0001 \\
\hline & Test critical values & $1 \%$ & -3.432329 & \\
\hline & & $5 \%$ & -2.862300 & \\
\hline & & $10 \%$ & -2.567219 & \\
\hline \multirow[t]{4}{*}{ Canada } & ADF test statistic & & -42.43039 & 0.0000 \\
\hline & Test critical values & $1 \%$ & -3.432245 & \\
\hline & & $5 \%$ & -2.862263 & \\
\hline & & $10 \%$ & -2.567199 & \\
\hline \multirow[t]{4}{*}{ Japan } & ADF test statistic & & -41.33271 & 0.0000 \\
\hline & Test critical values & $1 \%$ & -3.432376 & \\
\hline & & $5 \%$ & -2.862321 & \\
\hline & & $10 \%$ & -2.567230 & \\
\hline \multirow[t]{4}{*}{ Hong Kong } & ADF test statistic & & -27.22248 & 0.0000 \\
\hline & Test critical values & $1 \%$ & -3.432364 & \\
\hline & & $5 \%$ & -2.862315 & \\
\hline & & $10 \%$ & -2.567227 & \\
\hline \multirow[t]{4}{*}{ India } & ADF test statistic & & -50.67885 & 0.0001 \\
\hline & Test critical values & $1 \%$ & -3.432358 & \\
\hline & & $5 \%$ & -2.862313 & \\
\hline & & $10 \%$ & -2.567226 & \\
\hline \multirow[t]{4}{*}{ Malaysia } & ADF test statistic & & -24.01416 & 0.0000 \\
\hline & Test critical values & $1 \%$ & -3.432370 & \\
\hline & & $5 \%$ & -2.862318 & \\
\hline & & $10 \%$ & -2.567228 & \\
\hline
\end{tabular}

Source: Authors' calculations.

Next, we check forheteroskedasticity in the time series, which is one of the conditions for testing the GARCH $(1,1)$ model (Table 2). All series for the selected indices are heteroskedastic and the presence of the ARCH effect indicates time-varying volatility. These results imply that we should use the GARCH model to estimate the volatility of returns. Tables A2 to A8 in the Appendix show the auto correlation of all seven data series. 
Table 2: Results of heteroskedasticity test for $\mathrm{ARCH}$

\begin{tabular}{|c|c|c|c|c|}
\hline Market & Statistic & Value & Statistic & Value \\
\hline \multicolumn{5}{|l|}{ UK } \\
\hline & F-statistic & 170.378 & Prob. $\mathrm{F}(1,3029)$ & 0.000 \\
\hline & Obs. ${ }^{*}$ R-squared & 161.412 & Prob. chi-square(1) & 0.000 \\
\hline \multicolumn{5}{|c|}{ Singapore } \\
\hline & F-statistic & 177.211 & Prob. $\mathrm{F}(1,3013)$ & 0.000 \\
\hline & Obs. *R-squared & 167.478 & Prob. chi-square(1) & 0.000 \\
\hline \multicolumn{5}{|l|}{ Canada } \\
\hline & F-statistic & 343.627 & Prob. $\mathrm{F}(1,3137)$ & 0.000 \\
\hline & Obs. ${ }^{*} \mathrm{R}$-squared & 309.900 & Prob. chi-square(1) & 0.000 \\
\hline \multicolumn{5}{|l|}{ Japan } \\
\hline & F-statistic & 27.6316 & Prob. $F(1,2950)$ & 0.000 \\
\hline & Obs. ${ }^{*}$ R-squared & 27.3938 & Prob. chi-square(1) & 0.000 \\
\hline \multicolumn{5}{|c|}{ Hong Kong } \\
\hline & F-statistic & 486.478 & Prob. $F(1,2968)$ & 0.000 \\
\hline & Obs. ${ }^{*}$ R-squared & 418.252 & Prob. chi-square(1) & 0.000 \\
\hline \multicolumn{5}{|l|}{ India } \\
\hline & F-statistic & 123.645 & Prob. $F(1,2973)$ & 0.000 \\
\hline & Obs. ${ }^{*}$ R-squared & 118.788 & Prob. chi-square(1) & 0.000 \\
\hline \multicolumn{5}{|c|}{ Malaysia } \\
\hline & F-statistic & $1,568.65$ & Prob. $F(1,2961)$ & 0.000 \\
\hline & Obs. ${ }^{*}$ R-squared & $1,026.11$ & Prob. chi-square(1) & 0.000 \\
\hline
\end{tabular}

Source: Authors' calculations.

The ARCH and GARCH terms for all seven series emerge as highly significant after estimating the GARCH model. There turn series indicate persistent volatility clustering. If $\alpha$ (the $\mathrm{ARCH}$ term) and $\beta$ (the GARCH term) are close to 1,this indicates the persistence of volatility shocks in the market. If they are less than 1 , this implies that the volatility shocks will decrease over time. If the value of $\alpha+\beta$ is greater than 1 , this indicates that the intensity of the shock will increase overtime (Chou, 1988). The significant result obtained for the dummy variable reflects the impact of the event (the demutualization announcement) on the return series.

Table 3 gives the GARCH results for the UK stock market, where $\alpha=$ 0.07 and $\beta=0.92$; both these values are significant. The ARCH and GARCH results indicate persistent volatility shocks to stock returns in this market. The dummy variable is, however, insignificant, implying that the volatility that exists is not due to the news received (the demutualization 
announcement). In other words, the demutualization of the FTSE 100had no impact on market movements in the UK.

Table 3: GARCH results for UK stock market

\begin{tabular}{lcccc}
\hline Variable & Coefficient & SE & z-statistic & Prob. \\
\hline C & $6.90 \mathrm{E}-07$ & $2.30 \mathrm{E}-07$ & 2.999335 & 0.0027 \\
RESID(-1)^2 & 0.071671 & 0.008320 & 8.614570 & 0.0000 \\
GARCH(-1) & 0.920959 & 0.008710 & 105.7425 & 0.0000 \\
DF & $2.56 \mathrm{E}-07$ & $2.09 \mathrm{E}-07$ & 1.225630 & 0.2203 \\
\hline
\end{tabular}

Source: Authors' calculations.

Table 4presents the results for the Singapore market: both cand $\beta$ are significant with values of 0.12 and 0.87 , respectively. The ARCH and GARCH terms confirm the persistence of volatility in the market's stock returns. The dummy variable is, however, insignificant, implying that the volatility that exists is not due to the demutualization announcement. Thus, the demutualization of the STI had no impact on market movements in Singapore.

Table 4: GARCH results for Singapore stock market

\begin{tabular}{lcccc}
\hline Variable & Coefficient & SE & z-statistic & Prob. \\
\hline C & $2.53 E-06$ & $4.18 \mathrm{E}-07$ & 6.046118 & 0.0000 \\
RESID(-1)^2 & 0.121282 & 0.008320 & 14.58639 & 0.0000 \\
GARCH(-1) & 0.870308 & 0.007330 & 118.7655 & 0.0000 \\
DF & $-1.14 \mathrm{E}-07$ & $4.09 \mathrm{E}-07$ & -0.277770 & 0.7812 \\
\hline
\end{tabular}

Source: Authors' calculations.

Table 5yields significant values for $\alpha$ and $\beta 0.068$ and 0.92, respectively. The ARCH and GARCH terms thus indicate the persistence of volatility in returns for the Canadian stock market. The significant dummy variable implies that the demutualization announcement contributed significantly to this volatility. However, its negative coefficient means that the demutualization of the TSX decreased the volatility of returns. 
Table 5: GARCH results for Canadian stock market

\begin{tabular}{lcccc}
\hline Variable & Coefficient & SE & z-statistic & Prob. \\
\hline C & $1.32 \mathrm{E}-06$ & $2.41 \mathrm{E}-07$ & 5.473677 & 0.0000 \\
RESID(-1)^2 & 0.068120 & 0.005000 & 13.61245 & 0.0000 \\
GARCH(-1) & 0.924697 & 0.004790 & 193.0636 & 0.0000 \\
DF & $-5.89 \mathrm{E}-07$ & $2.14 \mathrm{E}-070$ & -2.756470 & 0.0058 \\
\hline
\end{tabular}

Source: Authors' calculations.

Table 6gives an ARCH term value of 0.084 and a GARCH term value of 0.89 ,both of which are significant. These confirm the presence of volatility clustering and persistence in the Japanese stock market. The significant dummy variable indicates that the decision to demutualize the Nikkei 225 contributed significantly to creating this volatility. Moreover, the impact of the information shock is likely to persist in the long run and decline slowly.

Table 6: GARCH results for Japanese stock market

\begin{tabular}{lcccc}
\hline Variable & Coefficient & SE & z-statistic & Prob. \\
\hline C & $3.09 \mathrm{E}-06$ & $6.95 \mathrm{E}-07$ & 4.443187 & 0.0000 \\
RESID $(-1)^{\wedge} 2$ & 0.084450 & 0.009080 & 9.304344 & 0.0000 \\
GARCH(-1) & 0.897107 & 0.011110 & 80.71619 & 0.0000 \\
DF & $2.04 \mathrm{E}-06$ & $6.96 \mathrm{E}-07$ & 2.935295 & 0.0033 \\
\hline
\end{tabular}

Source: Authors' calculations.

Table 7yields significant ARCH and GARCH term values of 0.07 and 0.92 , respectively. The value of $\alpha+\beta$ is equal to 1 , indicating volatility clustering and persistence in the Hong Kong stock market. The significant dummy variable reflects the impact of the demutualization announcement for the HSI. Thus, the information shock is persistent and likely to decline slowly.

Table 7: GARCH results for Hong Kong stock market

\begin{tabular}{lcccc}
\hline Variable & Coefficient & SE & z-statistic & Prob. \\
\hline C & $1.32 \mathrm{E}-06$ & $3.91 \mathrm{E}-07$ & 3.378125 & $7 \mathrm{E}-040$ \\
$\mathrm{RESID}(-1)^{\wedge} 2$ & 0.070921 & 0.006350 & 11.17693 & 0.0000 \\
GARCH(-1) & 0.922996 & 0.006920 & 133.3740 & 0.0000 \\
$\mathrm{DF}$ & $1.14 \mathrm{E}-06$ & $4.21 \mathrm{E}-07$ & 2.701895 & 0.0069 \\
\hline
\end{tabular}

Source: Authors' calculations. 
Although the ARCH and GARCH terms in Table 8areboth significant with values of 0.13 and 0.84 , respectively, the insignificant dummy variable indicates that the decision to demutualize the SENSEX did not affect Indian stock market returns. The volatility does not, therefore, incorporate the impact of the event, although there are signs of persistent volatility in the data.

Table 8: GARCH results for Indian stock market

\begin{tabular}{lcccc}
\hline Variable & Coefficient & SE & z-statistic & Prob. \\
\hline C & $6.48 \mathrm{E}-06$ & $9.24 \mathrm{E}-07$ & 7.020530 & 0.0000 \\
RESID $(-1)^{\wedge} 2$ & 0.133962 & 0.009000 & 14.88253 & 0.0000 \\
GARCH(-1) & 0.847536 & 0.008930 & 94.89060 & 0.0000 \\
DF & $1.02 \mathrm{E}-07$ & $8.90 \mathrm{E}-07$ & 0.114621 & 0.9087 \\
\hline
\end{tabular}

Source: Authors' calculations.

Table 9indicatesvolatility clustering and persistence in the case of the Malaysian stock market. Both the ARCH and GARCH terms (0.13 and 0.80 , respectively) are significant. The dummy variable is also significant, implying that the decision to demutualize the KLCI had a negative effect on the volatility of this market. Thus, the volatility of stock returns decreased after the demutualization was announced, although it still incorporates the impact of the announcement.

Table 9: GARCH results for Malaysian stock market

\begin{tabular}{lcccc}
\hline Variable & Coefficient & SE & z-statistic & Prob. \\
\hline C & $1.57 \mathrm{E}-05$ & $4.02 \mathrm{E}-07$ & 38.97273 & 0.0000 \\
RESID(-1)^2 & 0.131271 & 0.006760 & 19.42109 & 0.0000 \\
GARCH(-1) & 0.807440 & 0.004720 & 170.9136 & 0.0000 \\
DF & $-6.83 \mathrm{E}-06$ & $5.87 \mathrm{E}-07$ & -11.62340 & 0.0000 \\
\hline
\end{tabular}

Source: Authors' calculations.

\section{Conclusion}

We have used a sample of seven stock exchanges to measure the impact of demutualization announcements on market volatility. On applying the GARCH $(1,1)$ methodology, the results show that the Canadian, Japanese, Hong Kong, and Malaysian markets were able to incorporate the effect of demutualization announcements in their return volatility. However, post-event, the volatility of the Canadian and Malaysian markets was negative while that of the Japanese and Hong Kong markets was positive. The volatility of returns in these markets 
increased after demutualization was announced and the corresponding shock persisted in the long run, increasing overtime. In addition, the volatility of the previous period contributed to the volatility of the present period.

In the case of the other three stock markets in the UK, Singapore, and India, the impact of the demutualization announcements was insignificant, although volatility clustering and persistence remained significant. This implies that these markets, while volatile, did not incorporate the impact of demutualization. Their volatility is, therefore, due to other factors. Janakiramanan and Lamba (1998) report that similar locations and investor behavior can cause such markets to affect one another. Thus, a weak market in one country may be strongly influenced by a strong market in a neighboring country. This would imply that Asian markets such as Hong Kong and Japan might exercise a spillover effect on closer markets such as Pakistan, and we might expect demutualization in the latter to lead to volatility in the future.

In a country such as Pakistan where the demutualization of stock exchanges is still a relatively new practice, it would be advisable to manage the change effectively. Other countries where the process is underway are, for example, required to conduct market and geographical analyses before implementing the decision to demutualize. 


\section{References}

Aggarwal, R. (2002). Demutualization and corporate governance of stock exchanges. Journal of Applied Corporate Finance,15(1),105-112.

Ahmed, S., Butt, Z. B., \& Rehman, K. (2011). Demutualization of stock exchanges in Pakistan: Challenges and benefits. African Journal of Business Management,5(2),448-454.

Bollerslev, T. (1986). Generalized autoregressive conditional heteroskedasticity. Journal of Econometrics,31(3), 307-327.

Brooks, C. (2002). Introductory econometrics for finance. Cambridge: Cambridge University Press.

Chou, R.Y.(1988). Volatility persistence and stock valuations: Some empirical evidence using GARCH. Journal of Applied Econometrics,3(4),279-294.

Elliott, J. (2002). Demutualization of securities exchanges: A regulatory perspective(Working Paper No. 02/119). Washington, DC: International Monetary Fund.

Engle, R. F. (1982). Autoregressive conditional heteroskedasticity with estimates of the variance of UK inflation.Econometrica,50, 987-1008.

Engle, R. F., \& Ng, V.K. (1993).Measuring and testing the impact of news on volatility. Journal of Finance, 48(5), 1749-1778.

Hart, O., \&Moore, J. (1996). The governance of exchanges: Members' cooperatives versus outside ownership. Oxford Review of Economic Policy,12(4), 53-69.

Hazarika, S. (2004).Governance change in stock exchanges. Unpublished manuscript, Baruch College, City University of New York, NY.

Hughes, P. S., \& Zargar, E. (2006). Exchange demutualization. In The twelve-minute securities lawyer. Toronto, ON: Law Society of Upper Canada.

Islam, M. S., \& Islam, M. R. (2011). Demutualization: Pros and cons for Dhaka Stock Exchange (DSE). European Journal of Business and Management,3(12),24-33. 
Janakiramanan, S., \& Lamba, A. S. (1998).An empirical examination of linkages between Pacific Basin stock markets. Journal of International Financial Markets, Institutions and Money, 8(2), 155-173.

Joshi, P., \& Pandya, K. (2008). Exploring movements of stock price volatility in India. IUP Journal of Applied Finance,14(3),5-32.

Karmel, R. (2000). Turning seats into shares: Implications of demutualization for the regulation of stock exchanges. Unpublished manuscript, Brooklyn Law School, New York, NY.

Krishnamurti, C., Sequeira, J., \& Fangjian, F. U. (2003). Stock exchange governance and market quality. Journal of Banking and Finance, 27(9), 1859-1878.

Mendiola, A., \& O'Hara, M. (2003). Taking stock in stock markets: The changing governance of exchanges. Unpublished manuscript, Cornell University, Ithaca, NY.

Morimune, K. (2007). Volatility models. Japanese Economic Review,58(1), 123.

Morsy, A., \& Rwegasira, K. (2010). An empirical investigation of the demutualization impact on market performance of stock exchanges. International Research Journal of Finance and Economics, $40,38-58$.

Patra, T., \& Poshakwale, S. (2006). Economic variables and stock market returns: Evidence from the Athens stock exchange. Applied Financial Economics,16(13), 993-1005.

Samanta, P., \& Samanta, P. K. (2007). Impact of futures trading on the underlying spot market volatility. ICFAI Journal of Applied Finance, 13(10), 52-65.

Schmiedel, H. (2001). Technological development and concentration of stock exchanges in Europe(Discussion Paper No. 21/2001).Helsinki: Bank of Finland.

Schmiedel, H. (2002). Total factor productivity growth in European stock exchanges: A non-parametric frontier approach(Discussion Paper No. 11/2002). Helsinki: Bank of Finland. 
Scullion, M. (2001). Demutualization: The challenges facing global exchanges. In The Compaq handbook of world stock, derivative and commodity exchanges (pp. xxv-xxxii). London: Mondo Visione.

Serifsoy, B. (2008). Demutualization, outsider ownership and stock exchange performance: Empirical evidence(Working Paper No. 157). Frankfurt: Goethe University Frankfurt, Department of Finance.

Slimane, F. B. (2012). Stock exchange consolidation and return volatility. ManagerialFinance,38(6),606-627.

Treptow, F. (2006). The economics of demutualization: An empirical analysis of the securities exchange industry. Wiesbaden: Deutscher UniversitätsVerlag.

Worthington, A.C., \& Higgs, H. (2005).Market risk in demutualized self-listed stock exchanges: An international analysis of selected time-varying betas(Discussion Papers in Economics, Finance and International Competitiveness). Brisbane: Queensland University of Technology, School of Economics and Finance. 


\section{Appendix}

Table A1: Demutualization of major stock exchanges

\begin{tabular}{lllcl}
\hline Stock exchange & $\begin{array}{c}\text { Year of } \\
\text { demutualization }\end{array}$ & IPO listing date & $\begin{array}{c}\text { Domestic } \\
\text { market } \\
\text { capitalization }\end{array}$ & Major capitalization \\
\hline London Stock Exchange & 2000 & 20Jul 2001 & $2,865,243$ & $\begin{array}{l}\text { Equity } \\
\text { Euronext }\end{array}$ \\
& 2000 & 10Jul 2001 & $2,441,261$ & $\begin{array}{l}\text { Equity; equity, currency, commodity and interest } \\
\text { rate derivatives }\end{array}$ \\
Deutsche Börse & 2000 & 5Feb 2001 & $1,194,517$ & Equity; equity and interest rate derivatives \\
BME Spanish Exchanges & 2001 & No plan & 940,673 & Equity; equity and interest rate derivatives \\
Swiss Exchange & 2002 & No plan & 826,041 & Equity \\
BorsaItaliana & 1997 & No plan & 789,563 & Equity and equity derivatives \\
OMX Group & 1993 & 1Jan 1993 & 715,779 & Equity; equity and interest rate derivatives \\
Oslo Børs & 2001 & 28May 2001 & 141,624 & Equity and equity derivatives \\
Hellenic Stock Exchange & 1999 & 28Jul 2000 & 121,921 & Equity \\
Tokyo Stock Exchange & 2001 & 2006 & $3,557,674$ & Equity and equity derivatives \\
Osaka Stock Exchange & 2001 & 2Apr 2004 & $2,287,048$ & Equity and equity derivatives \\
Hong Kong Stock Exchange & 2000 & 27Jun 2000 & 861,463 & Equity; equity and interest rate derivatives \\
Singapore Stock Exchange & 1999 & 16Nov 2000 & 217,618 & Equity; equity and interest rate derivatives \\
Bursa Malaysia & 2004 & 18Mar 2005 & 181,624 & Equity; equity and interest rate derivatives \\
New Zealand Stock Exchange & 2003 & 4Jun 2003 & 43,731 & Equity \\
\hline
\end{tabular}

Source: Hughes and Zargar (2006). 
Table A2: Series of exchange indices for theUK

\begin{tabular}{|c|c|c|c|c|c|c|}
\hline Autocorrelation & Partial correlation & & $\mathrm{AC}$ & PAC & Q-stat & Prob. \\
\hline $\mid$ & || & 1 & 0.002 & 0.002 & 0.0121 & 0.912 \\
\hline 11 & 1 & 2 & -0.034 & -0.034 & 3.4235 & 0.181 \\
\hline$* 11$ & $* 11$ & 3 & -0.094 & -0.094 & 30.271 & 0.000 \\
\hline | | & | & 4 & 0.031 & 0.031 & 33.247 & 0.000 \\
\hline | | & | | & 5 & -0.035 & -0.041 & 36.886 & 0.000 \\
\hline | & | | & 6 & -0.043 & -0.050 & 42.455 & 0.000 \\
\hline | | & | | & 7 & -0.018 & -0.015 & 43.426 & 0.000 \\
\hline | | & | | & 8 & 0.049 & 0.038 & 50.708 & 0.000 \\
\hline $\mid$ & | & 9 & 0.032 & 0.025 & 53.898 & 0.000 \\
\hline | & | & 10 & -0.046 & -0.045 & 60.211 & 0.000 \\
\hline | | & | | & 11 & 0.008 & 0.017 & 60.431 & 0.000 \\
\hline | | & | & 12 & -0.010 & -0.013 & 60.740 & 0.000 \\
\hline | & | | & 13 & 0.037 & 0.030 & 64.888 & 0.000 \\
\hline | | & | | & 14 & -0.024 & -0.015 & 66.682 & 0.000 \\
\hline | & 11 & 15 & 0.032 & 0.033 & 69.822 & 0.000 \\
\hline $1 \mid$ & 11 & 16 & -0.018 & -0.017 & 70.839 & 0.000 \\
\hline 11 & 11 & 17 & -0.006 & -0.013 & 70.934 & 0.000 \\
\hline $1 \mid$ & 11 & 18 & -0.043 & -0.032 & 76.461 & 0.000 \\
\hline $1 \mid$ & 1 & 19 & -0.030 & -0.034 & 79.209 & 0.000 \\
\hline $1 \mid$ & 11 & 20 & 0.001 & -0.002 & 79.210 & 0.000 \\
\hline $1 \mid$ & 11 & 21 & -0.028 & -0.039 & 81.662 & 0.000 \\
\hline | & 1 & 22 & 0.042 & 0.037 & 87.027 & 0.000 \\
\hline $1 \mid$ & 11 & 23 & -0.039 & -0.044 & 91.703 & 0.000 \\
\hline | & 11 & 24 & 0.012 & 0.000 & 92.142 & 0.000 \\
\hline 1 & 1 & 25 & 0.006 & 0.014 & 92.237 & 0.000 \\
\hline 11 & 11 & 26 & 0.030 & 0.017 & 94.970 & 0.000 \\
\hline | & $1 \mid$ & 27 & -0.016 & -0.006 & 95.797 & 0.000 \\
\hline 11 & 11 & 28 & 0.023 & 0.022 & 97.462 & 0.000 \\
\hline $1 \mid$ & 11 & 29 & -0.003 & 0.003 & 97.491 & 0.000 \\
\hline $1 \mid$ & 11 & 30 & 0.028 & 0.024 & 99.969 & 0.000 \\
\hline $1 \mid$ & $1 \mid$ & 31 & -0.048 & -0.040 & 107.03 & 0.000 \\
\hline | | & | | & 32 & 0.011 & 0.020 & 107.39 & 0.000 \\
\hline 11 & 11 & 33 & -0.035 & -0.038 & 111.14 & 0.000 \\
\hline | | & | | & 34 & 0.030 & 0.026 & 113.94 & 0.000 \\
\hline $1 \mid$ & 11 & 35 & -0.005 & -0.007 & 114.00 & 0.000 \\
\hline i & $\therefore$ & 36 & 0.006 & 0.004 & 114.11 & 0.000 \\
\hline
\end{tabular}

Notes: Date $=01 / 06 / 2013$, time $=12: 18$

Sample period $=04 / 05 / 1994$ to $04 / 03 / 2006$, included observations $=3,032$. 
Table A3: Series of exchange indices for Singapore

\begin{tabular}{|c|c|c|c|c|c|c|}
\hline Autocorrelation & Partial correlation & & $\mathrm{AC}$ & PAC & Q-stat & Prob. \\
\hline$|*|$ & $|*|$ & 1 & 0.139 & 0.139 & 58.032 & 0.000 \\
\hline | | & | & 2 & 0.013 & -0.006 & 58.531 & 0.000 \\
\hline | & | & 3 & 0.020 & 0.020 & 59.747 & 0.000 \\
\hline | & | & 4 & 0.007 & 0.002 & 59.893 & 0.000 \\
\hline | | & | | & 5 & -0.011 & -0.012 & 60.255 & 0.000 \\
\hline | & $\mid$ & 6 & -0.032 & -0.030 & 63.443 & 0.000 \\
\hline 1 & 1 & 7 & -0.004 & 0.005 & 63.492 & 0.000 \\
\hline | & | | & 8 & -0.008 & -0.007 & 63.664 & 0.000 \\
\hline | & | & 9 & -0.021 & -0.018 & 65.008 & 0.000 \\
\hline 1 & 1 & 10 & 0.037 & 0.043 & 69.088 & 0.000 \\
\hline | | & | | & 11 & 0.035 & 0.024 & 72.763 & 0.000 \\
\hline|| & | & 12 & 0.009 & 0.001 & 73.012 & 0.000 \\
\hline | | & | | & 13 & 0.053 & 0.051 & 81.481 & 0.000 \\
\hline | & | & 14 & -0.000 & -0.018 & 81.482 & 0.000 \\
\hline | | & $\mid$ & 15 & -0.011 & -0.010 & 81.875 & 0.000 \\
\hline | | & | | & 16 & -0.003 & 0.001 & 81.899 & 0.000 \\
\hline $1 \mid$ & 11 & 17 & 0.007 & 0.009 & 82.056 & 0.000 \\
\hline $1 \mid$ & 11 & 18 & 0.005 & 0.005 & 82.145 & 0.000 \\
\hline 11 & 11 & 19 & -0.027 & -0.024 & 84.439 & 0.000 \\
\hline | & 11 & 20 & -0.013 & -0.007 & 84.945 & 0.000 \\
\hline 11 & 11 & 21 & -0.061 & -0.062 & 96.102 & 0.000 \\
\hline 11 & 11 & 22 & -0.009 & 0.011 & 96.339 & 0.000 \\
\hline 11 & 1 & 23 & 0.033 & 0.030 & 99.559 & 0.000 \\
\hline $1 \mid$ & 11 & 24 & 0.050 & 0.042 & 107.17 & 0.000 \\
\hline $1 \mid$ & $1 \mid$ & 25 & -0.000 & -0.013 & 107.17 & 0.000 \\
\hline $1 \mid$ & 11 & 26 & 0.017 & 0.016 & 108.10 & 0.000 \\
\hline $1 \mid$ & 11 & 27 & 0.007 & -0.003 & 108.25 & 0.000 \\
\hline 11 & 11 & 28 & 0.028 & 0.027 & 110.61 & 0.000 \\
\hline | & 11 & 29 & 0.017 & 0.013 & 111.48 & 0.000 \\
\hline | & | & 30 & 0.003 & -0.001 & 111.50 & 0.000 \\
\hline 11 & $1 \mid$ & 31 & 0.003 & 0.006 & 111.52 & 0.000 \\
\hline $1 \mid$ & 11 & 32 & -0.035 & -0.029 & 115.26 & 0.000 \\
\hline 11 & 11 & 33 & 0.022 & 0.032 & 116.72 & 0.000 \\
\hline $1 \mid$ & $1 \mid$ & 34 & 0.037 & 0.033 & 120.95 & 0.000 \\
\hline $1 \mid$ & | & 35 & -0.001 & -0.012 & 120.95 & 0.000 \\
\hline . & 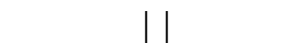 & 36 & -0.008 & -0.012 & 121.13 & 0.000 \\
\hline
\end{tabular}

Notes: Date $=01 / 01 / 2013$, time $=10: 32$

Sample period $=12 / 01 / 1993$ to $12 / 01 / 2005$, included observations $=3,016$. 
Table A4: Series of exchange indices for Canada

\begin{tabular}{|c|c|c|c|c|c|c|}
\hline Autocorrelation & Partial correlation & & $\mathrm{AC}$ & PAC & Q-stat & Prob. \\
\hline | & | | & 1 & -0.029 & -0.029 & 2.5759 & 0.109 \\
\hline | & | | & 2 & -0.053 & -0.054 & 11.493 & 0.003 \\
\hline | | & | | & 3 & 0.027 & 0.024 & 13.830 & 0.003 \\
\hline | & | | & 4 & -0.002 & -0.003 & 13.843 & 0.008 \\
\hline$* \mid 1$ & $* \mid 1$ & 5 & -0.073 & -0.071 & 30.566 & 0.000 \\
\hline | & || & 6 & -0.010 & -0.016 & 30.901 & 0.000 \\
\hline | | & | | & 7 & 0.018 & 0.010 & 31.903 & 0.000 \\
\hline | | & | | & 8 & 0.020 & 0.023 & 33.111 & 0.000 \\
\hline | | & | | & 9 & -0.017 & -0.015 & 34.070 & 0.000 \\
\hline|| & | | & 10 & 0.026 & 0.021 & 36.174 & 0.000 \\
\hline | | & | | & 11 & 0.012 & 0.009 & 36.612 & 0.000 \\
\hline | | & | | & 12 & -0.043 & -0.038 & 42.513 & 0.000 \\
\hline|| & | | & 13 & 0.041 & 0.042 & 47.722 & 0.000 \\
\hline | | & 11 & 14 & -0.005 & -0.009 & 47.794 & 0.000 \\
\hline | | & | | & 15 & -0.008 & -0.000 & 48.001 & 0.000 \\
\hline | | & | & 16 & 0.011 & 0.010 & 48.394 & 0.000 \\
\hline 11 & 11 & 17 & -0.051 & -0.056 & 56.625 & 0.000 \\
\hline | & | | & 18 & 0.013 & 0.015 & 57.194 & 0.000 \\
\hline 11 & 11 & 19 & -0.005 & -0.009 & 57.273 & 0.000 \\
\hline 11 & 11 & 20 & 0.005 & 0.009 & 57.359 & 0.000 \\
\hline 11 & 11 & 21 & 0.018 & 0.015 & 58.413 & 0.000 \\
\hline 11 & $1 \mid$ & 22 & 0.015 & 0.013 & 59.167 & 0.000 \\
\hline | & | & 23 & 0.027 & 0.030 & 61.541 & 0.000 \\
\hline 11 & 11 & 24 & -0.046 & -0.047 & 68.139 & 0.000 \\
\hline $1 \mid$ & | & 25 & 0.024 & 0.032 & 69.989 & 0.000 \\
\hline | & | & 26 & 0.050 & 0.044 & 77.879 & 0.000 \\
\hline 11 & 11 & 27 & -0.012 & 0.000 & 78.356 & 0.000 \\
\hline 11 & 11 & 28 & 0.040 & 0.049 & 83.302 & 0.000 \\
\hline | & | & 29 & 0.006 & -0.007 & 83.435 & 0.000 \\
\hline 11 & 11 & 30 & -0.043 & -0.031 & 89.412 & 0.000 \\
\hline $1 \mid$ & $1 \mid$ & 31 & 0.057 & 0.059 & 99.542 & 0.000 \\
\hline 11 & $1 \mid$ & 32 & -0.035 & -0.036 & 103.54 & 0.000 \\
\hline | & | & 33 & 0.035 & 0.046 & 107.46 & 0.000 \\
\hline | & $1 \mid$ & 34 & -0.024 & -0.032 & 109.27 & 0.000 \\
\hline 11 & | & 35 & -0.008 & -0.005 & 109.46 & 0.000 \\
\hline 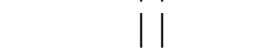 & 1 & 36 & 0.035 & 0.028 & 113.34 & 0.000 \\
\hline
\end{tabular}

Notes: Date $=01 / 04 / 2013$,time $=17: 21$

Sample period $=01 / 03 / 2000$ to $06 / 27 / 2012$, included observations $=3,140$. 
Table A5: Series of exchange indices for Japan

\begin{tabular}{|c|c|c|c|c|c|c|}
\hline Autocorrelation & Partial correlation & & $\mathrm{AC}$ & PAC & Q-stat & Prob. \\
\hline | & || & 1 & -0.042 & -0.042 & 5.1943 & 0.023 \\
\hline | & | | & 2 & -0.051 & -0.053 & 12.914 & 0.002 \\
\hline | & | & 3 & 0.036 & 0.032 & 16.836 & 0.001 \\
\hline | & | & 4 & -0.041 & -0.041 & 21.909 & 0.000 \\
\hline | | & | | & 5 & 0.018 & 0.018 & 22.825 & 0.000 \\
\hline | | & | | & 6 & -0.017 & -0.021 & 23.683 & 0.001 \\
\hline 1 & $\mid$ & 7 & -0.003 & 0.001 & 23.703 & 0.001 \\
\hline | | & | & 8 & -0.007 & -0.012 & 23.838 & 0.002 \\
\hline | | & | | & 9 & -0.014 & -0.012 & 24.428 & 0.004 \\
\hline 1 & 11 & 10 & 0.033 & 0.030 & 27.710 & 0.002 \\
\hline | | & | | & 11 & 0.007 & 0.009 & 27.856 & 0.003 \\
\hline | | & | | & 12 & 0.002 & 0.006 & 27.869 & 0.006 \\
\hline $\mid$ & | | & 13 & -0.001 & -0.002 & 27.870 & 0.009 \\
\hline | & | & 14 & -0.010 & -0.008 & 28.197 & 0.013 \\
\hline | & | | & 15 & 0.003 & 0.001 & 28.229 & 0.020 \\
\hline $\mid$ & | | & 16 & -0.047 & -0.047 & 34.770 & 0.004 \\
\hline | & 11 & 17 & 0.020 & 0.017 & 35.930 & 0.005 \\
\hline 11 & | & 18 & 0.027 & 0.024 & 38.162 & 0.004 \\
\hline 11 & 11 & 19 & -0.010 & -0.002 & 38.468 & 0.005 \\
\hline 1 & $1 \mid$ & 20 & -0.013 & -0.017 & 38.991 & 0.007 \\
\hline 11 & 11 & 21 & 0.005 & 0.005 & 39.080 & 0.010 \\
\hline $1 \mid$ & | & 22 & -0.018 & -0.020 & 40.059 & 0.011 \\
\hline | & | & 23 & -0.018 & -0.019 & 41.031 & 0.012 \\
\hline 11 & 11 & 24 & 0.031 & 0.027 & 43.848 & 0.008 \\
\hline $1 \mid$ & | & 25 & 0.021 & 0.023 & 45.144 & 0.008 \\
\hline | & | & 26 & -0.017 & -0.010 & 46.005 & 0.009 \\
\hline $1 \mid$ & 11 & 27 & -0.009 & -0.011 & 46.259 & 0.012 \\
\hline $1 \mid$ & $1 \mid$ & 28 & 0.025 & 0.022 & 48.198 & 0.010 \\
\hline | & 11 & 29 & 0.006 & 0.007 & 48.312 & 0.014 \\
\hline | & 11 & 30 & 0.002 & 0.005 & 48.328 & 0.018 \\
\hline $1 \mid$ & $1 \mid$ & 31 & -0.003 & -0.003 & 48.359 & 0.024 \\
\hline | | & | & 32 & 0.001 & 0.002 & 48.362 & 0.032 \\
\hline 11 & | & 33 & -0.001 & 0.001 & 48.369 & 0.041 \\
\hline $1 \mid$ & 11 & 34 & 0.006 & 0.007 & 48.463 & 0.051 \\
\hline $1 \mid$ & $1 \mid$ & 35 & -0.038 & -0.042 & 52.782 & 0.027 \\
\hline & . & 36 & -0.009 & -0.014 & 53.051 & 0.033 \\
\hline
\end{tabular}

Notes: Date $=01 / 01 / 2013$, time $=10: 16$

Sample period $=11 / 01 / 1995$ to $11 / 01 / 2007$, included observations $=2,953$. 
Table A6: Series of exchange indices for Hong Kong

\begin{tabular}{|c|c|c|c|c|c|c|}
\hline Autocorrelation & Partial correlation & & $\mathrm{AC}$ & PAC & Q-stat & Prob. \\
\hline|| & || & 1 & 0.032 & 0.032 & 2.9868 & 0.084 \\
\hline | | & | | & 2 & -0.039 & -0.040 & 7.5483 & 0.023 \\
\hline$\left.\right|^{*} \mid$ & $\left.\right|^{*} \mid$ & 3 & 0.086 & 0.089 & 29.687 & 0.000 \\
\hline|| & | | & 4 & -0.048 & -0.056 & 36.556 & 0.000 \\
\hline | | & | | & 5 & -0.049 & -0.038 & 43.760 & 0.000 \\
\hline | | & | | & 6 & 0.018 & 0.010 & 44.753 & 0.000 \\
\hline | | & | | & 7 & -0.014 & -0.010 & 45.338 & 0.000 \\
\hline|| & | | & 8 & 0.002 & 0.009 & 45.348 & 0.000 \\
\hline | | & | | & 9 & 0.016 & 0.008 & 46.152 & 0.000 \\
\hline | | & | | & 10 & 0.012 & 0.014 & 46.613 & 0.000 \\
\hline | | & | | & 11 & 0.026 & 0.025 & 48.604 & 0.000 \\
\hline | | & | | & 12 & 0.009 & 0.005 & 48.836 & 0.000 \\
\hline | | & | | & 13 & 0.032 & 0.034 & 51.906 & 0.000 \\
\hline | | & || & 14 & 0.010 & 0.006 & 52.234 & 0.000 \\
\hline | | & | | & 15 & -0.003 & 0.002 & 52.255 & 0.000 \\
\hline | | & | | & 16 & -0.038 & -0.041 & 56.601 & 0.000 \\
\hline $1 \mid$ & | & 17 & 0.005 & 0.010 & 56.684 & 0.000 \\
\hline | | & | | & 18 & -0.013 & -0.013 & 57.207 & 0.000 \\
\hline | | & | | & 19 & -0.022 & -0.014 & 58.636 & 0.000 \\
\hline 11 & $1 \mid$ & 20 & 0.024 & 0.019 & 60.389 & 0.000 \\
\hline | | & | | & 21 & 0.008 & 0.003 & 60.572 & 0.000 \\
\hline | | & || & 22 & -0.014 & -0.010 & 61.130 & 0.000 \\
\hline | & | | & 23 & 0.005 & -0.003 & 61.194 & 0.000 \\
\hline | | & | | & 24 & -0.029 & -0.032 & 63.698 & 0.000 \\
\hline | | & | | & 25 & -0.020 & -0.013 & 64.876 & 0.000 \\
\hline | | & | | & 26 & 0.001 & -0.003 & 64.878 & 0.000 \\
\hline | | & | | & 27 & 0.003 & 0.008 & 64.905 & 0.000 \\
\hline | & | | & 28 & 0.006 & 0.006 & 64.999 & 0.000 \\
\hline | | & | | & 29 & 0.031 & 0.031 & 67.938 & 0.000 \\
\hline | | & | | & 30 & -0.049 & -0.053 & 75.077 & 0.000 \\
\hline | | & | | & 31 & 0.005 & 0.011 & 75.152 & 0.000 \\
\hline | | & | | & 32 & 0.010 & 0.000 & 75.425 & 0.000 \\
\hline | | & | | & 33 & -0.007 & 0.006 & 75.579 & 0.000 \\
\hline | & | & 34 & 0.023 & 0.020 & 77.126 & 0.000 \\
\hline | & | | & 35 & 0.008 & 0.002 & 77.321 & 0.000 \\
\hline t & 11 & 36 & -0.016 & -0.008 & 78.055 & 0.000 \\
\hline
\end{tabular}

Notes: Date $=01 / 01 / 2013$, time $=10: 19$

Sample period $=03 / 01 / 1994$ to $03 / 08 / 2006$, included observations $=2,971$. 
Table A7: Series of exchange indices for India

\begin{tabular}{|c|c|c|c|c|c|c|}
\hline Autocorrelation & Partial correlation & & $\mathrm{AC}$ & PAC & Q-stat & Prob. \\
\hline $\mid$ | & $\mid 1$ & 1 & 0.073 & 0.073 & 15.891 & 0.000 \\
\hline | | & | & 2 & -0.035 & -0.041 & 19.596 & 0.000 \\
\hline | & | & 3 & -0.011 & -0.006 & 19.978 & 0.000 \\
\hline | & | & 4 & 0.015 & 0.015 & 20.650 & 0.000 \\
\hline | | & | | & 5 & -0.035 & -0.038 & 24.321 & 0.000 \\
\hline | & $\mid$ & 6 & -0.053 & -0.047 & 32.789 & 0.000 \\
\hline 1 & 1 & 7 & 0.024 & 0.029 & 34.443 & 0.000 \\
\hline | & | | & 8 & 0.044 & 0.036 & 40.230 & 0.000 \\
\hline | & | & 9 & 0.037 & 0.033 & 44.343 & 0.000 \\
\hline 1 & 1 & 10 & 0.023 & 0.021 & 45.858 & 0.000 \\
\hline | | & | | & 11 & -0.019 & -0.024 & 46.984 & 0.000 \\
\hline|| & | & 12 & -0.001 & 0.002 & 46.990 & 0.000 \\
\hline | | & | | & 13 & 0.016 & 0.019 & 47.717 & 0.000 \\
\hline | & | & 14 & 0.036 & 0.039 & 51.608 & 0.000 \\
\hline | | & $\mid$ & 15 & -0.009 & -0.010 & 51.844 & 0.000 \\
\hline | | & | | & 16 & 0.010 & 0.012 & 52.120 & 0.000 \\
\hline $1 \mid$ & 11 & 17 & 0.046 & 0.038 & 58.356 & 0.000 \\
\hline $1 \mid$ & 11 & 18 & -0.006 & -0.014 & 58.460 & 0.000 \\
\hline $1 \mid$ & $1 \mid$ & 19 & -0.037 & -0.028 & 62.467 & 0.000 \\
\hline $1 \mid$ & $1 \mid$ & 20 & -0.044 & -0.037 & 68.189 & 0.000 \\
\hline 11 & 11 & 21 & 0.002 & 0.001 & 68.197 & 0.000 \\
\hline | & | & 22 & 0.008 & 0.004 & 68.371 & 0.000 \\
\hline 11 & 11 & 23 & 0.020 & 0.021 & 69.617 & 0.000 \\
\hline $1 \mid$ & 11 & 24 & 0.014 & 0.006 & 70.190 & 0.000 \\
\hline | & | & 25 & 0.025 & 0.018 & 72.067 & 0.000 \\
\hline | & | & 26 & 0.002 & -0.005 & 72.084 & 0.000 \\
\hline $1 \mid$ & 11 & 27 & 0.007 & 0.011 & 72.227 & 0.000 \\
\hline 11 & 11 & 28 & -0.000 & 0.006 & 72.227 & 0.000 \\
\hline | & | & 29 & -0.034 & -0.029 & 75.783 & 0.000 \\
\hline 11 & 11 & 30 & -0.015 & -0.011 & 76.502 & 0.000 \\
\hline | & | & 31 & 0.002 & -0.003 & 76.510 & 0.000 \\
\hline $1 \mid$ & 11 & 32 & -0.004 & -0.006 & 76.556 & 0.000 \\
\hline 11 & 11 & 33 & 0.000 & 0.003 & 76.556 & 0.000 \\
\hline $1 \mid$ & $1 \mid$ & 34 & -0.018 & -0.021 & 77.493 & 0.000 \\
\hline $1 \mid$ & | & 35 & 0.019 & 0.017 & 78.552 & 0.000 \\
\hline$\pi$ & 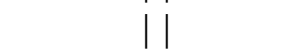 & 36 & -0.024 & -0.026 & 80.360 & 0.000 \\
\hline
\end{tabular}

Notes: Date $=01 / 01 / 2013$, time $=10: 24$

Sample period: 05/19/1999 to 05/20/2011,included observations $=2,976$. 
Table A8: Series of exchange indices for Malaysia

\begin{tabular}{|c|c|c|c|c|c|c|}
\hline Autocorrelation & Partial correlation & & $\mathrm{AC}$ & PAC & Q-stat & Prob. \\
\hline$* \mid$ & $* \mid 1$ & 1 & -0.093 & -0.093 & 25.625 & 0.000 \\
\hline 1 & 11 & 2 & 0.025 & 0.017 & 27.549 & 0.000 \\
\hline | | & | & 3 & 0.024 & 0.028 & 29.256 & 0.000 \\
\hline$* \mid 1$ & $* 11$ & 4 & -0.092 & -0.088 & 54.356 & 0.000 \\
\hline$\left.\right|^{*} \mid$ & $\left.\right|^{*} \mid$ & 5 & 0.093 & 0.076 & 79.841 & 0.000 \\
\hline $\mid$ & $\mid$ & 6 & -0.020 & -0.002 & 80.997 & 0.000 \\
\hline $\mid$ & || & 7 & 0.014 & 0.012 & 81.553 & 0.000 \\
\hline | | & | | & 8 & 0.006 & -0.003 & 81.658 & 0.000 \\
\hline | & | & 9 & 0.004 & 0.019 & 81.706 & 0.000 \\
\hline $\mid$ & | & 10 & 0.018 & 0.010 & 82.618 & 0.000 \\
\hline | | & $\left.\right|^{*} \mid$ & 11 & 0.069 & 0.076 & 96.690 & 0.000 \\
\hline | | & || & 12 & 0.011 & 0.020 & 97.032 & 0.000 \\
\hline | | & | & 13 & -0.042 & -0.043 & 102.37 & 0.000 \\
\hline|| & || & 14 & 0.060 & 0.051 & 112.94 & 0.000 \\
\hline 11 & $1 \mid$ & 15 & -0.011 & 0.010 & 113.29 & 0.000 \\
\hline $\mid$ & $* 1$ & 16 & -0.058 & -0.071 & 123.26 & 0.000 \\
\hline $1^{*} \mid$ & $\left.\right|^{*} \mid$ & 17 & 0.105 & 0.088 & 156.10 & 0.000 \\
\hline | & 11 & 18 & -0.056 & -0.024 & 165.37 & 0.000 \\
\hline 1 & 1 & 19 & -0.022 & -0.045 & 166.81 & 0.000 \\
\hline $1 \mid$ & 11 & 20 & 0.035 & 0.022 & 170.49 & 0.000 \\
\hline 11 & 11 & 21 & 0.011 & 0.043 & 170.87 & 0.000 \\
\hline 1 & 1 & 22 & 0.026 & -0.002 & 172.85 & 0.000 \\
\hline 11 & 11 & 23 & -0.012 & -0.008 & 173.31 & 0.000 \\
\hline 11 & | & 24 & 0.017 & 0.027 & 174.18 & 0.000 \\
\hline 1 & 1 & 25 & 0.055 & 0.052 & 183.08 & 0.000 \\
\hline 11 & 11 & 26 & -0.024 & -0.019 & 184.79 & 0.000 \\
\hline $1 \mid$ & $1 \mid$ & 27 & 0.025 & 0.028 & 186.64 & 0.000 \\
\hline 11 & | & 28 & 0.004 & -0.003 & 186.68 & 0.000 \\
\hline | | & 11 & 29 & -0.001 & 0.004 & 186.68 & 0.000 \\
\hline $1 \mid$ & 11 & 30 & 0.022 & 0.029 & 188.09 & 0.000 \\
\hline 11 & $1 \mid$ & 31 & 0.005 & -0.002 & 188.16 & 0.000 \\
\hline | | & | | & 32 & 0.012 & -0.002 & 188.61 & 0.000 \\
\hline 11 & $1 \mid$ & 33 & -0.005 & 0.012 & 188.69 & 0.000 \\
\hline | | & | | & 34 & 0.020 & 0.007 & 189.88 & 0.000 \\
\hline 11 & 11 & 35 & 0.021 & 0.016 & 191.21 & 0.000 \\
\hline 11 & 11 & 36 & 0.016 & 0.020 & 191.93 & 0.000 \\
\hline
\end{tabular}

Notes: Date $=01 / 01 / 2013$, time $=10: 27$

Sample $=04 / 13 / 1998$ to $04 / 14 / 2010$,included observations $=2,964$. 